\title{
The bitter taste of medicine
}

\author{
Giorgio Bordin
}

Received: 7 February 2012/ Accepted: 16 February 2012/Published online: 21 March 2012

(C) Springer-Verlag 2012

It was used to say that the bitter the medicine, the better the cure.

Many remedies were in old ages really awful to drink as Adriaen Brouwer has comically depicted in his canvas, set in the middle of the XVII century.

It is a fact that the chemical modification which led Felix Hoffmann [1, 2] (a German chemist) to obtain acetilsalicilic acid, was moved by the bad taste of salicilic raw extract, which his father was taking for arthritis. Felix Hoffmann worked in a small company called Bayer. How much the unpredictable fortune of Aspirin and of Bayer could be explained also by a matter of taste could be a kind of gossip, but I agree that it is not an odd hypothesis.

I'm old enough to remember, in my childhood, unpleasant tonics which have today no longer place in the restyled market of drugs, where flavoury drinks, no-taste pills, and disposable transdermic or parenteral devices acquaint anyone that bad times have forever gone, because alchemy has been defeated by science.

But medicine has a bitter taste in his own genoma, which no technological progress can sweeten.

In its fight against evil and death, medicine can win a battle but loses the war. The disease that seems to be beaten, rises embodied in new, more powerful figures, like an evil alien in some science fiction horror movie.

A physician or a nurse need to swallow this reality without too many grimaces, and front the idea that the cure of the sicks emerges for the ability of take care of a diseased man or woman, even in front of failure and death.

G. Bordin ( $\square)$

Hospital Piccole Figlie, Parma, PR, Italy

e-mail: gbordinas@inwind.it

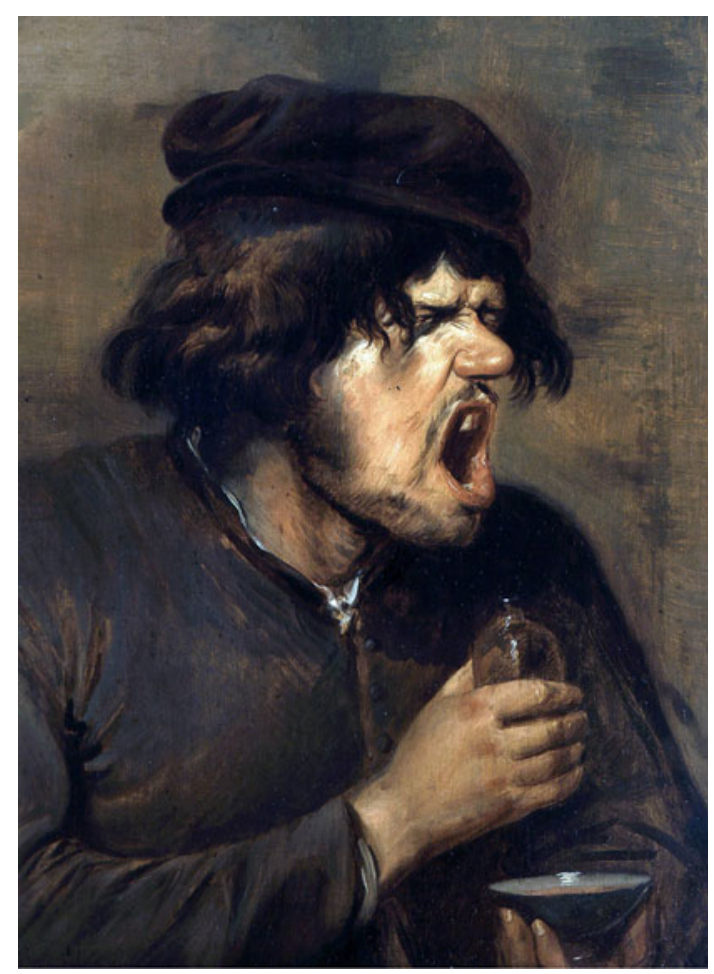

Brouwer, Adriaen (1605-1638) The bitter medicine. A man wincing while drinking a medicine 17th century. Musee des Beaux-Arts, Dijon, France. (C2012 Scala Archives

This means, in our work, trying to heal with every human effort, but at the same time holding the idea that salubrity and salvation (which have their common root in the latin word salus) are not mechanical products of progress and science, so avoiding the convincement to have in our hands the happiness of the humankind.

Once upon a time it was also used to coat the bitter pill with anything could sweeten the taste. Technology is 
needed and grows up over reliable and solid arguments, but we fear that its hi-tech aseptic glamour could be used also to sugar the pill and to escape a hard struggle with ethic and responsibility.

\section{References}

1. Pasero G, Marson P (2010) Piccola storia della terapia antireumatica. II. L'aspirina. Reumatismo 62(2):148-156

2. Sneader W (2000) The discovery of aspirin: a reappraisal. BMJ 321:1591-1594 